\title{
Design and Application
}

\section{of Slow-Release Pesticide Formulations Embedded in a Biodegradable Matrix Based on Poly(3-Hydroxybutyrate)}

\author{
Svetlana V. Prudnikova*a and Tatiana G. Volova ${ }^{a, b}$ \\ aSiberian Federal University \\ 79 Svobodny, Krasnoyarsk, 660041, Russia \\ ${ }^{b}$ Institute of Biophysics SB RAS \\ FRC "Krasnoyarsk Science Center SB RAS" \\ 50/50 Akademgorodok, Krasnoyarsk, 660036, Russia
}

Received 20.02.2019, received in revised form 23.04.2019, accepted 13.05.2019

The latest trend in agriculture is the development and application of environmentally friendly pesticides with targeted and controlled release of active ingredients embedded in biodegradable polymer bases. In this work, a series of experimental slow-release pesticide formulations was produced using composites of degradable polyester poly(3-hydroxybutyrate) and natural materials as a matrix for embedding two agrochemicals - a fungicide (tebuconazole) and an herbicide (metribuzin). The structure, physicochemical properties and degradation rate of long-term formulations and the kinetics of active ingredient release from the matrix were studied in laboratory soil microecosystems. The experimental formulations allowed for a gradual release of agrochemicals into the soil for two months without abrupt emissions, providing long-term plant protection against pathogens and weeds. In contrast to the free forms of the agrochemicals, the analysis showed an absence of noticeable shifts and negative impacts on soil bacterial communities with the introduction of the developed formulations. The fungicidal action of long-term tebuconazole was confirmed on model Triticum aestivum plants infected with a complex of root rot pathogens (Alternaria, Fusarium, and Bipolaris). The efficacy of embedded metribuzin on model Melilotus albus weeds was comparable to that of the free forms of this herbicide. This work has produced new data on biodegradable polyhydroxyalkanoates for constructing long-term formulations of agropreparations. The fundamentals have been provided for constructing environmentally friendly and targeted controlled-release formulations of crop protection products against pathogens and weeds.

Keywords: pesticides, slow-release formulations, poly(3-hydroxybutyrate), fillers, degradable matrix, soil microbiology.

(C) Siberian Federal University. All rights reserved

This work is licensed under a Creative Commons Attribution-NonCommercial 4.0 International License (CC BY-NC 4.0).

* Corresponding author E-mail address: sveet_s@bk.ru

ORCID: 0000-0001-8990-3043 (Prudnikova S.V.); 0000-0001-9392-156X (Volova T.G.) 


\title{
Разработка и применение систем доставки пестицидов, депонированных в биоразлагаемую матрицу на основе поли-3-гидроксибутирата
}

\author{
С.В. Прудникова ${ }^{\mathrm{a}}$, Т.Г. Волова ${ }^{\mathrm{a}, \boldsymbol{\sigma}}$ \\ ${ }^{a}$ Сибирский федеральный университет \\ Россия, 660041, Красноярск, пр. Свободный, 79 \\ ${ }^{6}$ Институт биофизики СО РАН \\ ФИЦ «Красноярский научный центр СО РАН» \\ Россия, 660036, Красноярск, Академгородок, 50/50
}

Новейтей тенденцией в сельском хозяйстве является применение экологически чистых пестицидов с иеленаправленным и контролируемым высвобождением активных ингредиентов, депонированных в биоразлагаемую основу. В представленной работе описана серия полученных препаратов (фунгицида тебуконазола и гербицида метрибузина) с контролируемым выходом из композитной основы из разлагаемого полимера поли-3-гидроксибутирата и природных материалов. Исследованы структура, физико-химические свойства, скорости разложения основы и выхода действующих веществ в лабораторных почвенных микроэкосистемах. Сформированные составы основы создали условия постепенного выхода препаратов в почву в течение двух месяиев без резких выбросов, обеспечивая долговременную защиту растений от патогенных микроорганизмов и сорняков. Показано отсутствие негативных действий форм на почвенные бактериальные сообщества. Фунгициное действие тебуконазола подтверждено на модельных растениях Triticum аеstivuт, зараженных комплексом возбудителей корневых гнилей (Alternalia, Fusarium, Bipolaris). Эффективность депонированного метрибузина была сопоставимой со свободной формой гербицида при исследовании в посевах сорняков Melilotus albus. Работа показала перспективность биоразлагаемых полигидроксиалканоатов для создания долгосрочных форм агропрепаратов с контролируемым выходом действующих веществ с иелью защиты культурных растений от патогенных микроорганизмов и сорняков.

Ключевые слова: пестициды, контролируемые системы доставки, поли-3-гидроксибутират, филлеры, разрушаемый матрикс, почвенная микробиология.

\section{Introduction}

The global chemical pollution of the biosphere is a topical issue. In this context, the widespread use of various chemicals in agriculture gives rise to concern about possible imbalances in ecosystems (Aktar et al., 2009). Pesticides - chemical plant protection products pose a particular risk to the environment: the 
range of pesticide formulations is growing, and the volume of use is increasing year by year (Lamichhane et al., 2016). Despite this, most of the chemicals used do not reach their intended target and are dispersed in water and soil ecosystems, accumulating in trophic chains. A reduction of the number and species diversity of animal, plant, and microorganism populations caused by the release of pesticides in the environment is observed with systematic use of formulations (Carvalho, 2017; Gavrilescu et al., 2015).

The development of environmentally friendly pesticides with controlled release of active agents is a new approach to mitigating the problem of soil pollution by agrochemicals. These formulations are slowly degraded in the soil by microbial enzymes, preventing a sudden release of embedded ingredients into the environment and providing effective action throughout the growing season without the repeated treatments of plants (Grillo et al., 2014; Roy et al., 2014). The development of slow-release formulations requires suitable materials that are compatible with pesticides and can decompose in the soil without negative effects on plants and microorganisms. Polyhydroxyalkanoates(PHAs) are promising materials as a polymer base for such a matrix. PHAs have unique properties, such as biodegradability, environmental safety, the ability to decompose into nontoxic products, and the ability to remain in the soil for several weeks (Volova et al., 2013; Yusoff et al., 2016). However, the degradation rate of the polymer matrix in soil and the release of active substances depend on many factors, including the preparation method, the amount of pesticide in the formulation, soil and climatic conditions, and the enzymatic activity of PHAdegrading microorganisms (Volova et al., 2017). The addition of organic components as fillers makes it possible to vary the composition of the polymer matrix and regulate the release rate of the active ingredients within a wide range. The use of organic amendments (green compost, activated sludge, etc.) also reduces the negative impact of pesticides on the enzymatic activity in the soil (Angelini et al., 2014; García-Delgado et al., 2018).

This work is aimed at designing environmentally friendly pesticide formulations using the advanced biodegradable poly(3hydroxybutyrate) $[\mathrm{P}(3 \mathrm{HB})]$ as a matrix.

\section{Materials and methods}

The study included three stages: 1) design of formulations and evaluation of their physicochemical properties; 2) analysis of the profiles of agrochemical release into the soil and the impact of pesticides on the soil microflora; and 3) assessment of the effectiveness of formulations for plant protection from pathogens and weeds.

Based on a literature review and our preliminary studies, two pesticides were selected: an herbicide (metribuzin) and a fungicide (tebuconazole). These agrochemicals meet the following criteria: high efficiency, applicability on a large scale in agriculture, suitability for soil applications, compatibility with polymer matrices in different phase states, stability in nonpolar organic solvent solutions and amenability to analysis by spectrophotometric methods. To design slow-release pesticide formulations, we used two- and three-component systems: "P(3HB)/pesticide" and "P(3HB)/filler/pesticide". Experimental formulations were shaped as films, granules and pellets loaded with $10 \%(\mathrm{w} / \mathrm{w})$ pesticides. Two-component mixtures of $\mathrm{P}(3 \mathrm{HB})$ and the corresponding pesticide solutions were taken to prepare granules by precipitation in hexane and films by evaporation of the solvent. To prepare pellets, the powders of $\mathrm{P}(3 \mathrm{HB})$ and the pesticide were mixed and cold pressed 
using an automatic press (Usilennyi Superpress, Byelorussia). For three-component formulations, we used wood flour as a filler. Pellets were made by cold pressing homogenous mixtures of the components "polymer/filler/pesticide" at a ratio of 50/40/10. Granules were prepared by wetting the components with ethanol and mixing them in a screw granulator (Fimar, Italy). The physicochemical properties of the formulations were studied by differential scanning calorimetry, Fourier-transform infrared spectroscopy (FTIR), and X-ray diffraction analysis as described by Volova et al. (2016).

To evaluate the degradation rates and release profiles of the agrochemicals, we constructed and characterized laboratory soil microecosystems with agro-transformed field soil (Volova et al., 2018). The structure of soil microbial communities was studied by conventional methods of soil microbiology. The dominant microbial species, including primary degraders of $\mathrm{P}(3 \mathrm{HB})$, were isolated and identified by MALDI time-of-flight mass spectrometry using a MALDI-TOF mass spectrometer (Bruker, Germany). The effect of the developed formulations on the soil microbial community was determined by plating soil suspensions on nutrient media. The efficiency of the developed formulations was studied on test plants of wheat (Triticum aestivum) in laboratory soil microecosystems. Melilotus albus were taken as a model weed. T. aestivum infected with a phytopathogenic root rot complex (Alternaria, Bipolaris, and Fusarium fungi) was used to evaluate the efficacy of fungicides for plant protection. Free forms of the pesticides metribuzin and tebuconazole applied in concentrations recommended by the manufacturer were used as a positive control. The negative control did not contain any pesticides.

\section{Results and discussion}

Using various techniques, a series of metribuzin (MET) and tebuconazole (TEB) formulations deposited in a polymer matrix based on $\mathrm{P}(3 \mathrm{HB})$ was obtained. Fig. 1 shows photographs of the two- and three-component embedded forms of TEB (as an example) with different shapes and geometries of the formulations.

Thermal and spectral analyses of the starting materials and experimental formulations showed that loading the polymer base with chemicals did not produce any noticeable effect on its physicochemical properties. The IR spectrum contains absorption bands characteristic of the fungicide and materials of the matrix. The presence of two melting peaks in the thermograms also confirms that the pesticide and polymer formed a stable mechanical mixture, and no chemical binding of the components was detected (Volova et al., 2016).

$\mathrm{P}(3 \mathrm{HB})$-matrix is an attractive substrate for soil bacteria and fungi; therefore, it is degraded by microbial enzymes, providing a gradual release of embedded substances into the soil. The kinetics of polymer sample degradation depended on the shape and method of preparation. The profiles of

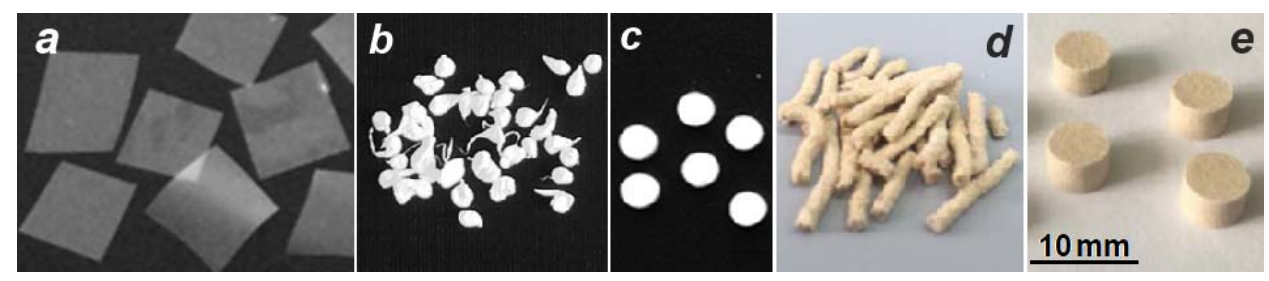

Fig. 1. Embedded formulations of two- and three-component fungicides loaded with $10 \%$ tebuconazole. $\mathrm{P}(3 \mathrm{HB}) /$ TEB: $a$ - films, $b$ - granules, $c$ - pellets; $\mathrm{P}(3 \mathrm{HB}) /$ wood flour/TEB: $d$-granules, $e-$ pellets 
the release of agrochemicals from experimental formulations were examined with respect to the geometry of formulations, type of chemicals, load of polymer bases and the degradation rate of polymer matrices in soil laboratory systems. Embedding metribuzin and tebuconazole into degradable bases enabled a slow burst-free release of active ingredients in soil. The highest degradation rate of two-component formulations was detected in film-shaped forms (Fig. 2). Granules and pellets degraded at slower rates, which affected MET and TEB release. Destruction of pellets was the slowest, as the high density formulation made by pressing impeded the degradation of the polymer matrix and reduced active ingredient release.

It is known that the response of soil microorganisms to the impact of pesticides is highly diverse and depends on many factors: the chemical structure of the pesticide, persistence of preparations, soil characteristics, the hydrothermal index, etc. (Kah et al., 2007). The study of the interaction of pesticides with soil microorganisms has indicated that the soil microflora plays a key role in soil fertility and plant growth promotion, as well as in the ability of microorganisms to biodegrade pesticides to safe substances in the environment (Chen et al., 2015).
The initial field soil was chernozem with a heavy loam granulometric texture. The abundance of organotrophic bacteria was $15.7 \times 10^{6} \mathrm{CFU} \cdot \mathrm{g}^{-1}$ of soil. The coefficients of oligotrophy and mineralization were 11.4 and 7.4, respectively, indicating that the content of ammonium and nitrate nitrogen was deficient. The introduction of free pesticides into the soil adversely affected microorganisms, reducing the number of organotrophic bacteria by 10-50 times compared to that in the native soil. A taxonomic study of the soil microbial community showed the dominance of Bacillus and Stenotrophomonas in the control soil without pesticides (Fig. 3). A selective effect of pesticides on soil microcenosis was revealed. Thus, in samples with MET, the proportion of gram-negative bacteria increased to $53.0 \%$, particularly Pseudomonas brassicacearum and $P$. kilonensis. In contrast, in soil samples with free TEB, the percentage of gram-positive bacteria increased to $90 \%$. The embedding of pesticides into the polymer matrix reduced the negative effect of chemicals on the microflora: the abundance of organotrophs did not reduce, and the ratio of the dominant taxa of bacteria (Bacillus and Stenotrophomonas) remained the same as at the control level.

The efficiency of the formulations was evaluated on test plants in laboratory soil
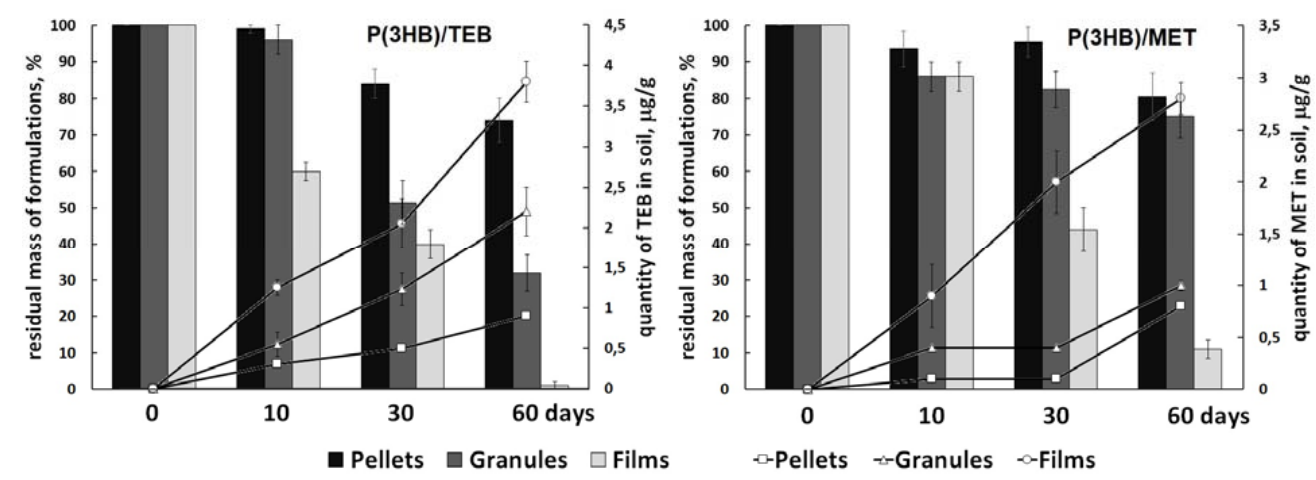

Fig. 2. Degradation dynamics of two-component formulations (\%) and cumulative release of metribuzin and tebuconazole into soil $(\mu \mathrm{g} / \mathrm{g})$ in laboratory soil microecosystems 


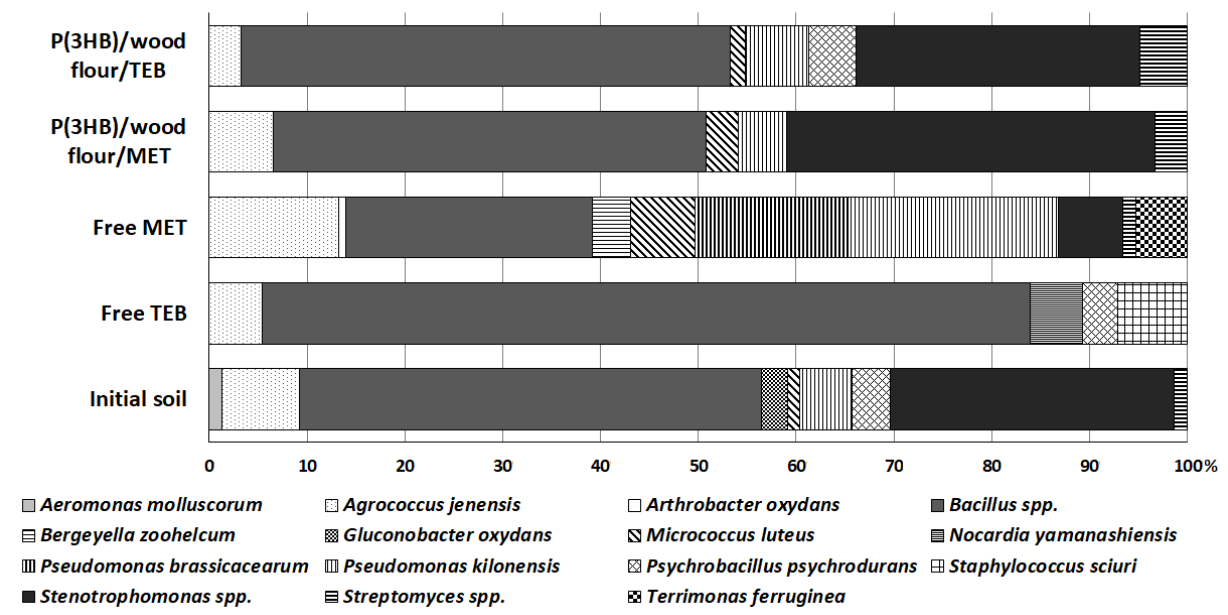

Fig. 3. The ratio of the dominant bacteria in soil samples with three-component granules and free pesticide application

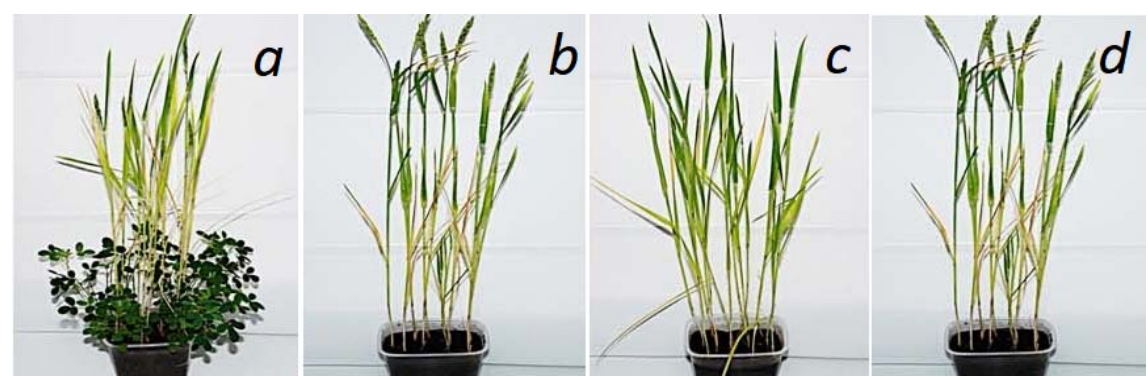

Fig. 4. The growth suppression of Melilotus albus by two-component metribuzin formulations: $a$ - negative control; $b$ - positive control (MET); $c-\mathrm{P}(3 \mathrm{HB}) / \mathrm{MET}$ films; $d-\mathrm{P}(3 \mathrm{HB}) / \mathrm{MET}$ granules

ecosystems. In the herbicide-treated ecosystems, both free and embedded forms of metribuzin reduced the aboveground biomass of weeds during the experiment. As a result, complete suppression of the growth of weeds was observed after 30 days (Fig. 4). In the initial period, the efficiency of two-component $\mathrm{P}(3 \mathrm{HB}) / \mathrm{MET}$ formulations was lower than that of the free herbicide. However, after 30 days, a prolonged effect and higher activity of the experimental formulations compared to those of the free MET became obvious.

The antifungal effect of embedded forms of three-component $\mathrm{P}(3 \mathrm{HB}) /$ wood flour/TEB granules was studied on wheat seedlings infected by phytopathogenic fungi. After 10 days, experimental TEB formulations insignificantly increased seed germination and reduced root rot infection by $46.8-54.7 \%$ compared with those of the control, and the antifungal effect was equal to that of the free TEB (Fig. 5). All forms of fungicides had the maximum healing effect on the development of the wheat root system, while the height and biomass of the aboveground segments of plants were not significantly changed.

Thus, the slow-release formulations of TEB stimulated the growth of the root system and prevented the infection of wheat seedlings with root rot. 

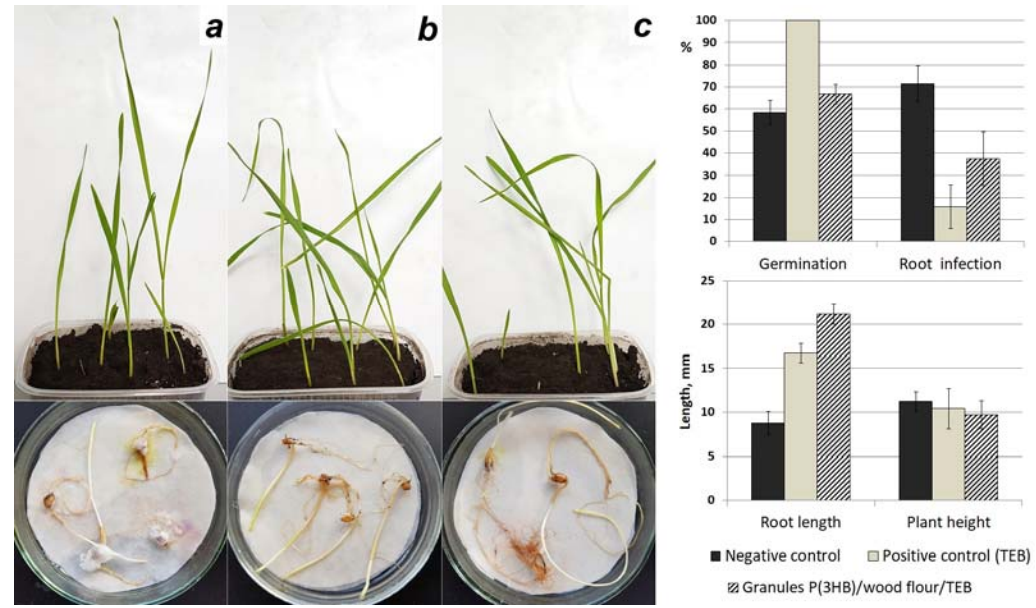

Fig. 5. Wheat seedling development with the introduction of three-component tebuconazole formulations: $a-$ negative control; $b$ - positive control (TEB); $c$-granules $\mathrm{P}(3 \mathrm{HB}) /$ wood flour/TEB

\section{Conclusion}

The studies have allowed for developing ways of loading chemicals into variously shaped and composed polymer bases and designing agricultural formulations intended to suppress plant pathogens and weeds. The obtained results suggest that the use of polyhydroxyalkanoates amended with natural materials as a degradable matrix is an effective approach to constructing slow-release formulations of agrochemicals. Further research in this direction can help to manage the risks of accumulation and uncontrolled distribution of pollutants in the environment and replace dead-end synthetic plastics with degradable materials capable of entering the biospheric cycles.

\section{Acknowledgements}

This study was financially supported by the project "Agropreparations of the new generation: a strategy of construction and realization" (Agreement No 074-02-2018-328) in accordance with Resolution No 220 of the Government of the Russian Federation of April 9, 2010, “On measures designed to attract leading scientists to the Russian institutions of higher learning".

\section{References}

Aktar W., Sengupta D., Chowdhury A. (2009) Impact of pesticides use in agriculture: their benefits and hazards. Interdisciplinary Toxicology, 2(1): 1-12

Angelini S., Cerruti P., Immirzi B., Santagata G., Scarinzi G., Malinconico M. (2014) From biowaste to bioresource: effect of a lignocellulosic filler on the properties of poly (3-hydroxybutyrate). International Journal of Biological Macromolecules, 71: 163-173

Carvalho F.P. (2017) Pesticides, environment, and food safety. Food and Energy Security, 6(2): 48-60

Chen M., Xu P., Zeng G., Yang C., Huang D., Zhang J. (2015) Bioremediation of soils contaminated with polycyclic aromatic hydrocarbons, petroleum, pesticides, chlorophenols and heavy metals by composting: applications, microbes and future research needs. Biotechnology Advances, 33(6): 745-755 
García-Delgado C., Barba V., Marín-Benito J.M., Igual J.M., Sánchez-Martín M.J., RodríguezCruz M.S. (2018) Simultaneous application of two herbicides and green compost in a field experiment: Implications on soil microbial community. Applied Soil Ecology, 127: 30-40

Gavrilescu M., Demnerová K., Aamand J., Agathos S., Fava F. (2015) Emerging pollutants in the environment: present and future challenges in biomonitoring, ecological risks and bioremediation. New Biotechnology, 32(1): 147-156

Grillo R., Pereira A.E.S., Nishisaka C.S., de Lima R., Oehlke K., Greiner R., Fraceto L.F. (2014) Chitosan/tripolyphosphate nanoparticles loaded with paraquat herbicide: an environmentally safer alternative for weed control. Journal of Hazardous Materials, 278: 163-171

Kah M., Beulke S., Brown C.D. (2007) Factors influencing degradation of pesticides in soil. Journal of Agricultural and Food Chemistry, 55(11): 4487-4492

Lamichhane J.R., Dachbrodt-Saaydeh S., Kudsk P., Messéan A. (2016) Toward a reduced reliance on conventional pesticides in European agriculture. Plant Disease, 100(1): 10-24

Roy A., Singh S.K., Bajpai J., Bajpai A.K. (2014) Controlled pesticide release from biodegradable polymers. Central European Journal of Chemistry, 12(4): 453-469

Volova T.G., Shishatskaya E.I., Sinskey A.J. (2013) Degradable polymers: Production, properties, applications. New York, Nova Science Publishers Inc., 380 p.

Volova T.G., Zhila, N.O., Vinogradova O.N., Nikolaeva E.D., Kiselev E.G., Shumilova A.A., Shershneva A.M., Shishatskaya E.I. (2016) Constructing herbicide metribuzin sustained-release formulations based on the natural polymer poly-3-hydroxybutyrate as a degradable matrix. Journal of Environmental Science and Health, Part B-Pesticides, Food Contaminants, and Agricultural Wastes, 51(2): $113-125$

Volova T.G., Prudnikova S.V., Vinogradova O.N., Syrvacheva D.A., Shishatskaya E.I. (2017) Microbial degradation of polyhydroxyalkanoates with different chemical compositions and their biodegradability. Microbial Ecology, 73(2): 353-367

Volova T.G., Prudnikova S.V., Zhila N.O. (2018) Fungicidal activity of slow-release P(3HB)/TEB formulations in wheat plant communities infected by Fusarium moniliforme. Environmental Science and Pollution Research, 25(1): 552-561

Yusoff S.N.M., Kamari A., Aljafree N.F.A. (2016) A review of materials used as carrier agents in pesticide formulations. International Journal of Environmental Science and Technology, 13(12): 2977-2994 